\title{
Analysis of Twelve Cardiovascular Disease Related Gene Mutations among Turkish Patients with Coronary Artery Disease

\author{
Gulsah Durmus ${ }^{1}$, Nevin Karakus ${ }^{2 *}$, Serkan Yuksel ${ }^{3}$ and Nurten Kara ${ }^{1}$ \\ ${ }^{1}$ Department of Medical Biology, Faculty of Medicine, Ondokuz Mayis University, Samsun, Turkey \\ ${ }^{2}$ Department of Medical Biology, Faculty of Medicine, Tokat Gaziosmanpasa University, Tokat, Turkey
}

${ }^{3}$ Department of Cardiology, Faculty of Medicine, Ondokuz Mayis University, Samsun, Turkey

*Corresponding author: Dr. Nevin Karakus, Department of Medical Biology, Faculty of Medicine, Tokat Gaziosmanpasa University, 60100, Tokat/Turkey, Tel: +9035-6212-9500/7317, Fax: +9035-6213-3179

\begin{abstract}
Background: Coronary artery disease (CAD) is a multifactorial disorder. It is important to identify gene mutations that may be responsible for the development of CAD. The aim of this study was to determine the frequency of twelve cardiovascular disease (CVD) related gene mutations in coronary artery patients.

Methods: The CVD StripAssay (Vienna Lab, Austria) was performed to analyze the twelve gene mutations on 52 coronary artery patients and 39 healthy controls. After DNA isolation from blood samples, hybridization with biotin marked probes was performed to PCR products containing the related region of mutant genes. Chisquare tests were used for statistical analyses.

Results: Any differences were not observed between coronary artery patients and healthy controls in terms of the frequencies of studied twelve gene mutations except MTHFR A1298C mutation. It was observed that heterozygous and homozygous mutant genotypes of MTHFR A1298C mutation have protective effects against coronary artery disease $[p=0.06$, in $95 \% \mathrm{Cl}$ OR $=0.205(0.0421$ 1.001)]. Although all the three genotypes of PAl-1 $4 \mathrm{G} / 5 \mathrm{G}, \mathrm{ACE}$ I/D and MTHFR C677T mutations were observed in both groups; homozygous mutant genotypes weren't observed for the Factor V Leiden, Factor V H1299R, Prothrombin G20210A, Factor XIII V34L, $\beta$-Fibrinojen -455G > A, HPA-1 1a/1b mutations in any of the groups. Heterozygote and homozygote mutant genotypes of APOB R3500Q mutation was not seen in both groups. When the patient group was evaluated in terms of compound genotypes, the rate of two mutations (ACE I/D, MTHFR A1298C) was $56 \%$, the rate of three mutations (PAl-1 4G/5G, MTHFR A1298C, ACE I/D) was $53 \%$, the rate of four mutations (PAI-1 4G/5G, MTHFR A1298C HPA-1 1a/1b, ACE I/D) was $33 \%$. High cholesterol, the number of clogged arteries and smoking rates was high in CAD patients with compound genotypes or carrying mutations in multiple genes compared the others.

Conclusion: Among 12 studied gene mutations, only the MTHFR A1298C mutation was determined to have a protective effect against CAD. In addition, cumulative effects of the mutant genotypes and environmental factors on people with the combined genotypes may be trigger for CAD.
\end{abstract}

\begin{abstract}
Keywords
Gene mutation, Coronary artery, MTHFR, CVD StripAssay

Abbreviations

ACE: Angiotensin I Converting Enzyme; APC: Activated Protein C; APOB: Apolipoprotein B; APOE: Apolipoprotein E; CAD: Coronary Artery Diseases; CVD: Cardiovascular Disease; FVL: FV Leiden; HDL: High Density Lipoprotein; HPA1: Human Platelet Antigen 1; LDL: Low Density Lipoprotein; MI: Myocardial Infarction; MTHFR: Methylene Tetrahydrofolate Reductase; PAI-1: Plasminogen Activator Inhibitor 1; PCR: Polymerase Chain Reaction; SNP: Single Nucleotide Polymorphisms; VTE: Venous Thromboembolism
\end{abstract}

\section{Introduction}

Coronary artery disease (CAD) is a multifactorial, chronic and inflammatory disease in which etiology, environmental and genetic factors play a role [1]. CAD is the leading cause of cardiovascular mortality in the World especially in developing countries [2,3]. Athero-sclerosis in coronary arteries and hypertension have important roles in the development of CAD $[4,5]$. Hopkins and Williams published a list of over 240 risk factors for CAD [6]. These include smoking, high total cholesterol, increased low density lipoprotein (LDL), decreased high density lipoprotein (HDL), hypertension, stable life, obesity and diabetes. Many genetic risk factors have also been identified $[6,7]$. Identification of gene variants and their roles that may be responsible for the development of CAD, can play an important role in understanding the key metabolic pathways and pathophysiology of the disease. CAD plays an important role in cardiovas-

Citation: Durmus G, Karakus N, Yuksel S, Kara N (2020) Analysis of Twelve Cardiovascular Disease Related Gene Mutations among Turkish Patients with Coronary Artery Disease. Int J Blood Res Disord 7:047. doi.org/10.23937/2469-5696/1410047

Accepted: February 10, 2020: Published: February 12, 2020

Copyright: (C) 2020 Durmus G, et al. This is an open-access article distributed under the terms of the Creative Commons Attribution License, which permits unrestricted use, distribution, and reproduction in any medium, provided the original author and source are credited. 
cular disease (CVD)'s clinical course $[4,8]$. For this reason, the CVD related gene mutations that were defined to CVD StripAssay are good candidates for genetic studies of CAD. This strip includes 12 mutations in 10 genes. These genes are Angiotensin I converting enzyme (ACE), apolipoprotein $B(A P O B)$, Fibrinogen, Coagulation factor XIII A chain (F13A1, Factor XIII), coagulation factor V (F5, FV), Human Platelet Antigen 1 (HPA1, Gp IIla, integrin subunit beta 3 ), Methylene tetrahydrofolate reductase (MTHFR), Plasminogen Activator Inhibitor 1 (PAI-1, SERPINE1), Prothrombin (PTH; F2, coagulation factor II, thrombin) and Apolipoprotein E (APOE).

ACE converts angiotensin I into angiotensin II, an effective vasoconstrictor, which leads to the destruction of vasodilator bradykinin. ACE levels are associated with 287 bp insertion/deletion (I/D) mutation in the ACE gene [9]. I/D mutation indicate a risk factor for myocardial infarction (MI) in older patients and in smokers; the $D$ allele is associated with elevated ACE activity and plasma levels [10].

Familial defective $A P O B$ is a cause of autosomal dominant hypercholesterolemia [11]. There is evidence suggesting that various variations of $A P O B$ may increase the risk of CAD [12]. R3500Q is a dominant but rare mutation, which is associated with severe hypercholesterolemia and elevated risk for atherosclerosis [11].

Fibrinogen is a glycoprotein located in the long arm of chromosome 4 (4q23-32) and containing 2 copies of 3 polypeptide chains encoded by 3 different genes $(\alpha$, $\beta, \gamma)$ [13]. Several studies have shown that variations of the fibrinogen beta chain (FGB, $\beta$-fibrinogen) gene are associated with increased severity of CAD $[14,15]$. $-455 \mathrm{G}>\mathrm{A}$ mutation increases the risk for premature $\mathrm{MI}$ and ischemic stroke [16]. In most studies it was shown that those carrying the $-455 \mathrm{~A}$ allele have higher plasma fibrinogen levels [14]. This leads to a large clot formation and an increased risk of arterial thrombosis.

Factor XIII is a transglutaminase. Val34Leu (V34L) mutation in the F13A1 gene occurs at the cleavage site of the F13A1 activation peptide. The mutation causes enzyme deficiency and bleeding disorders $[17,18]$. The $L$ variant offers a protective effect against venous thromboembolism (VTE) [19].

Single nucleotide polymorphisms (SNP) in the F5 gene have been shown to play a major role in $C A D$ development [20]. FV Leiden (FVL) (1691G > A; R506Q) mutation in $\mathrm{F} 5$ destroys the major proteolytic cleavage site recognized by activated protein $\mathrm{C}$ (APC), and FV becomes resistant to APC, but has normal procoagulant activity [21]. FVL inactivates 10 times slower than normal F5 and remains in circulation longer and a predisposition to coagulation occurs [21]. The risk of VTE, peripheral vascular diseases, stroke, pulmonary embolism increases in individuals with FVL mutation and it also causes recurrent miscarriages, second and third trimester pregnancy losses, preeclampsia, placental abrasion, intrauterine growth retardation [22]. FV R2 haplotype (H1299R) have a mild risk factor for thrombosis; increases CVD risk for carriers of FV Leiden [23].

HPA1 gene $1 \mathrm{a} / 1 \mathrm{~b}$ (L33P) mutation has been associated with acute coronary events, $\mathrm{Ml}$ and stroke predisposition at early ages [24].

MTHFR is an important enzyme in folate metabolism. The C677T and A1298C mutations of MTHFR gene have been described as risk factors for CAD, stroke, neural tube defects, Down syndrome, breast and endometrial cancers [25].

In the promoter region (675 base pairs prior to the start of transcription) of the PAI-1 gene, an insertion or deletion mutation (4G/5G) was detected [26]. The 4G allele is associated with higher PAl-1 transcription rates [26]. An increase in plasma PAI-1 level could damage the fibrinolytic system and lead to a permanent fibrin clot. Therefore, this mutation may help to evaluate the performance of the fibrinolytic system in the diagnosis of CAD.

The G20210A mutation in the 3'-untranslated region of the PTH gene was reported to be associated with increased prothrombin levels in plasma and a tendency to thrombosis [27].

The affinity of lipoproteins containing APOE to lipoprotein receptors increases from APOE-E2 to APOE-E3 and APOE-E4. As the allele number increases (E2, E3 and E4) APOE decreases and plasma cholesterol, LDL-cholesterol and APO B increase [28].

In our study, we aimed to investigate the mutations of Factor $V$, Prothrombin, Factor XIII, $\beta$-Fibrinogen, PAI1, HPA1, MTHFR, ACE, APOB and APOE genes in patients with coronary artery disease.

\section{Materials and Methods}

\section{Study population}

In this study, a total of 92 individuals, 52 coronary artery patients ( 47 males and 5 females) aged between 32 and 54 years (mean age \pm SD: $47.6 \pm 5.8$ years) and 39 healthy controls ( 24 females and 15 males) aged between 19 and 60 years (mean age \pm SD: $44.8 \pm 9.8$ years) were examined. The CAD patients were treated and followed up in the Cardiology Department of Ondokuz Mayis University Research Hospital, Samsun, Turkey. All the unrelated participants (patients and controls) were from Northern Turkey. The clinical data of patients including hypertension, diabetes, hypercholesterolemia, family history of CAD, smoking habits and number of diseased vessels were recorded (Table 1). Coronary risk factors were defined according to following criterions: hypertension was defined if the patients' blood pressure was $>140 / 90 \mathrm{mmHg}$ 
or if they were receiving any antihypertensive treatment; diabetes was defined if they were receiving any antidiabetic medication; hypercholesterolemia, was considered when their triglyceride concentra-

Table 1: Clinical characteristics of CAD patients.

\begin{tabular}{|l|l|}
\hline Characteristics & CAD patients \\
\cline { 2 - 3 } & $\mathbf{n = 5 2}(\mathbf{\%})$ \\
\hline Smoking & $44(84.6)$ \\
\hline Hypertension & $14(26.9)$ \\
\hline Diabetes mellitus & $9(17.3)$ \\
\hline Hypercholesterolemia & $17(32.7)$ \\
\hline Family history of CAD & $31(59.6)$ \\
\hline Number of diseased vessel & \\
\hline \multicolumn{1}{|c|}{ One vessel } & $21(40.4)$ \\
\hline Two vessels & $13(25.0)$ \\
\hline Three vessels & $18(34.6)$ \\
\hline
\end{tabular}

tion was > $200 \mathrm{mg} / \mathrm{dL}$, their total cholesterol concentration was $>200 \mathrm{mg} / \mathrm{dL}$, or they were receiving lipid-lowering drugs. Smoking habit was defined as never and current smoker. The family history of CAD was defined as positive if at least one first-degree relative was diagnosed with CAD. Coronary angiography was applied to all patients. If the luminal diameter of at least one epicardial coronary artery was narrowed by $>50 \%$, coronary stenosis was accepted significant. The exclusion critters for control group were hypertension, diabetes, hypercholesterolemia and family history of CAD and CVD.

The study was approved by the Ondokuz Mayıs University Clinical Research Ethics Committee with the decision number 2011/330 and informed consent was obtained from the patient and control group volunteers.

Laboratory analysis

DNA was purified by salting out method from $5 \mathrm{ml}$

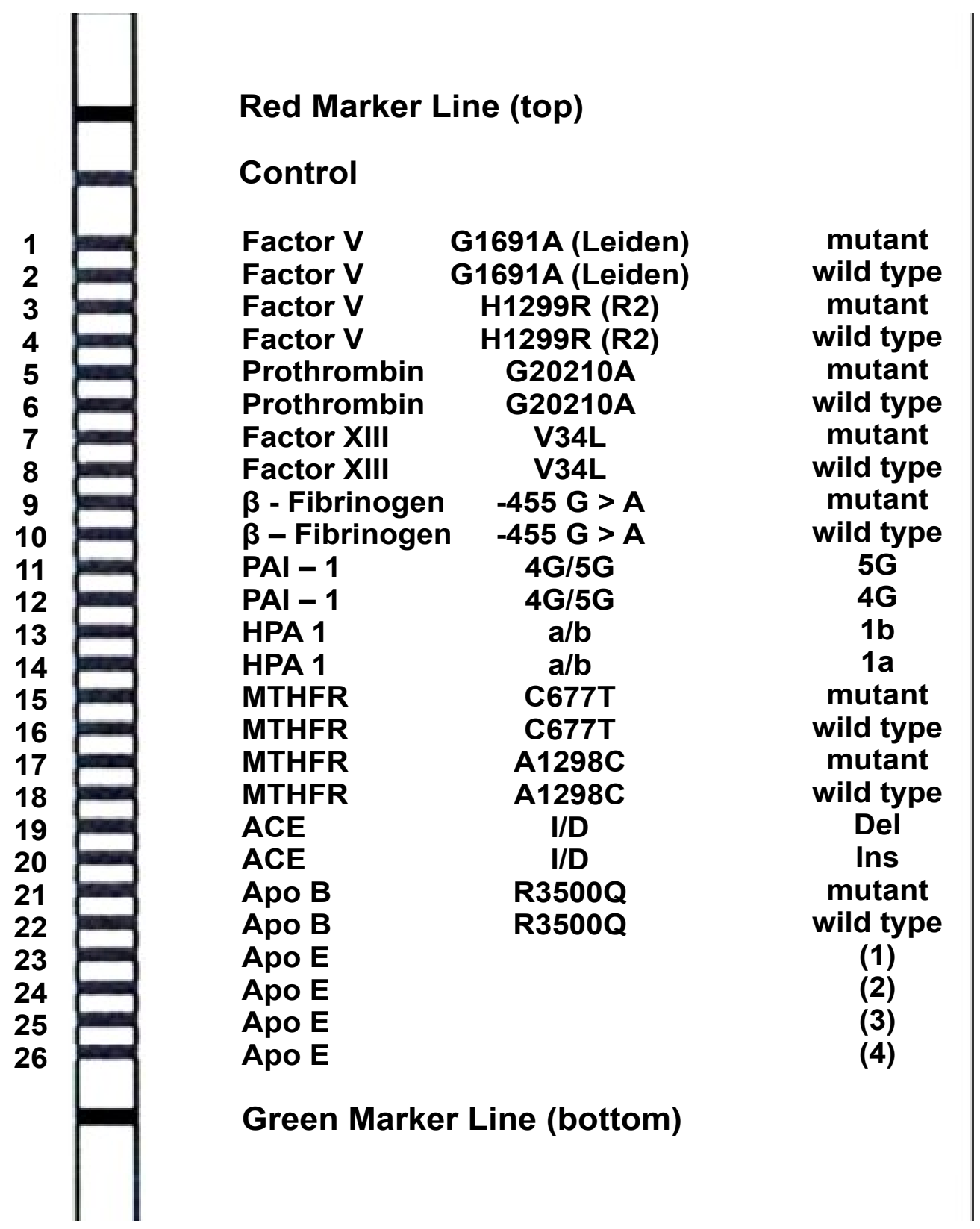

Figure 1: Band paterns of 26 bands in CVD Strip (Vienna Lab). 
blood samples and stored at $-20{ }^{\circ} \mathrm{C}$. Polymerase chain reaction (PCR) and reverse-hybridization kit (Vienna Lab CVD Strip Assay Kit) assays done for mutation analysis according to the instructions described by the manufacturer (ViennaLab Labordiagnostika GmbH, Vienna, Austria, www.viennalab.com) Shortly, for amplifying different gene sequences, a multiplex PCR in a single reaction tube were made and simultaneously biotin-labeled. The PCR conditions were as follows: $94^{\circ} \mathrm{C}$ for $2 \mathrm{~min}$, followed by 35 cycles of $94{ }^{\circ} \mathrm{C}$ for $15 \mathrm{~s}, 58^{\circ} \mathrm{C}$ for $30 \mathrm{~s}, 72$ ${ }^{\circ} \mathrm{C}$ for $30 \mathrm{~s}$, and a final extension step of $72{ }^{\circ} \mathrm{C}$ for $3 \mathrm{~min}$. Lastly, the PCR products were selectively hybridized to a test strip that include allele-specific oligonucleotide probes immobilized as an array of parallel lines. Then streptavidin-alkaline phosphatase and color substrates were used to detect bound biotinylated sequences. The CVD strip, demonstrating the band patterns of the mutant type and wild type alleles of the genes, is shown in Figure 1. For the genotypes of normal individuals, only wild bands should be positive, for heterozygous individuals both wild and mutant bands, and for homozygous mutant individuals only mutant bands should be positive. Six possible homozygous and heterozygous APOE genotypes (E2/2, E3/3, E4/4, E2/3, E2/4, and E3/4) could be obtained for the APOE isoforms E2, E3 and E4.

\section{Statistical analysis}

As a result of the analysis of the patients and controls, mutation distributions in the related genes were estimated by using SPSS 15.0 statistical program. Gene mutations and compound genotypes in coronary artery patients and healthy controls were compared by chisquare analysis (Open Epi Version 3.03).

\section{Results}

CVD StripAssay results and genotypes for twelve mutations of two cases are shown in Figure 2. The frequency of related gene mutations for all coronary artery patients and healthy controls are shown in Table 2. According to the results, except MTHFR A1298C mutation, any differences were not observed between coronary artery patients and healthy controls in terms of the frequencies of studied gene mutations. Coronary artery patients had homozygous wild-type genotype for MTHFR A1298C significantly more often than healthy controls $(p=0.008)$. When AA: AC + CC genotypes were compared in the patient and control groups, heterozygous and homozygous mutant genotypes had shown to have protective effects against $C A D[p=0.06, O R=0.205$ (0.0421-1.001) in 95\% confidence interval]. Homozygous mutant genotypes weren't observed for the Factor V Leiden, Factor V H1299R, Prothrombin G20210A, Factor XIII V34L, $\beta$-Fibrinojen -455G > A, HPA-1 1a/1b mutations in both groups. All the three genotypes of PAI-1 4G/5G, ACE I/D and MTHFR C677T mutations were observed in cases and controls. Heterozygote and homozygote mutant genotypes of APOB R3500Q mutation

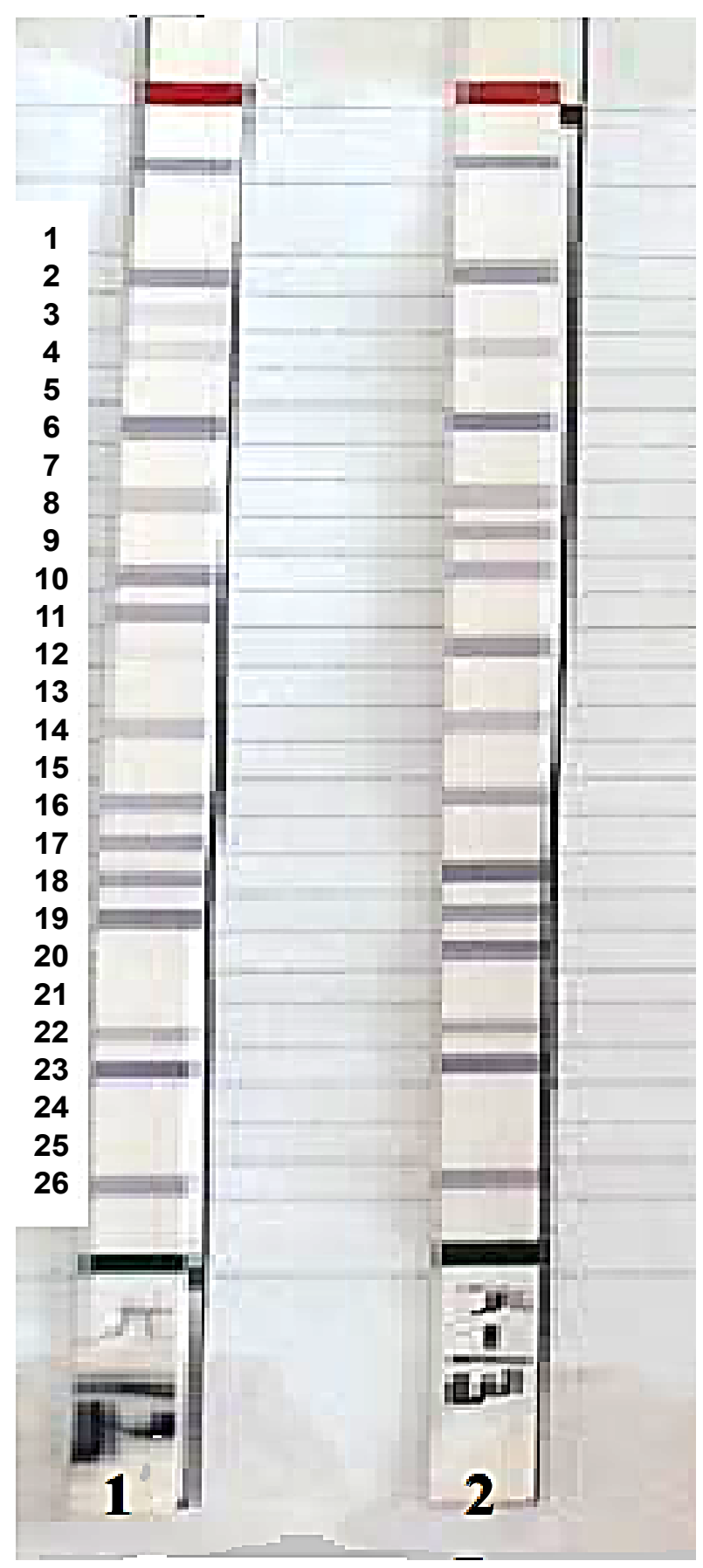

Figure 2: CVD StripAssay results of two cases. Both cases are homozygote wild type for Factor $V$ Leiden, Prothrombin G20210A, Factor XIII V34L, MTHFR C677T and APOB R3500Q; Number 1 is heterozygote and Number 2 is homozygote wild type for Factor V H1299R and MTHFR A1298C; Number 1 is homozygote wild type and Number 2 is heterozygote for $\beta$-Fibrinojen $-455 G>A$; Number 1 is $5 \mathrm{G} / 5 \mathrm{G}$ and number 2 is $4 \mathrm{G} / 4 \mathrm{G}$ for PAI- 1 ; both the cases are $1 \mathrm{a} / 1 \mathrm{a}$ for HPA-1; Number 1 is del/del and Number 2 is del/ins for ACE; both the cases are E3/E3 for APOE.

was not seen in any of the groups.

When the mutations observed in the patient group were evaluated, it was observed that there were individuals carrying more than one mutation in different genes. These include; in 26 (56\%) of 46 patients, two mutations (ACE I/D, MTHFR A1298C), in 8 (53\%) of 15 patients, three mutations (PAI-14G/5G, MTHFR A1298C, 


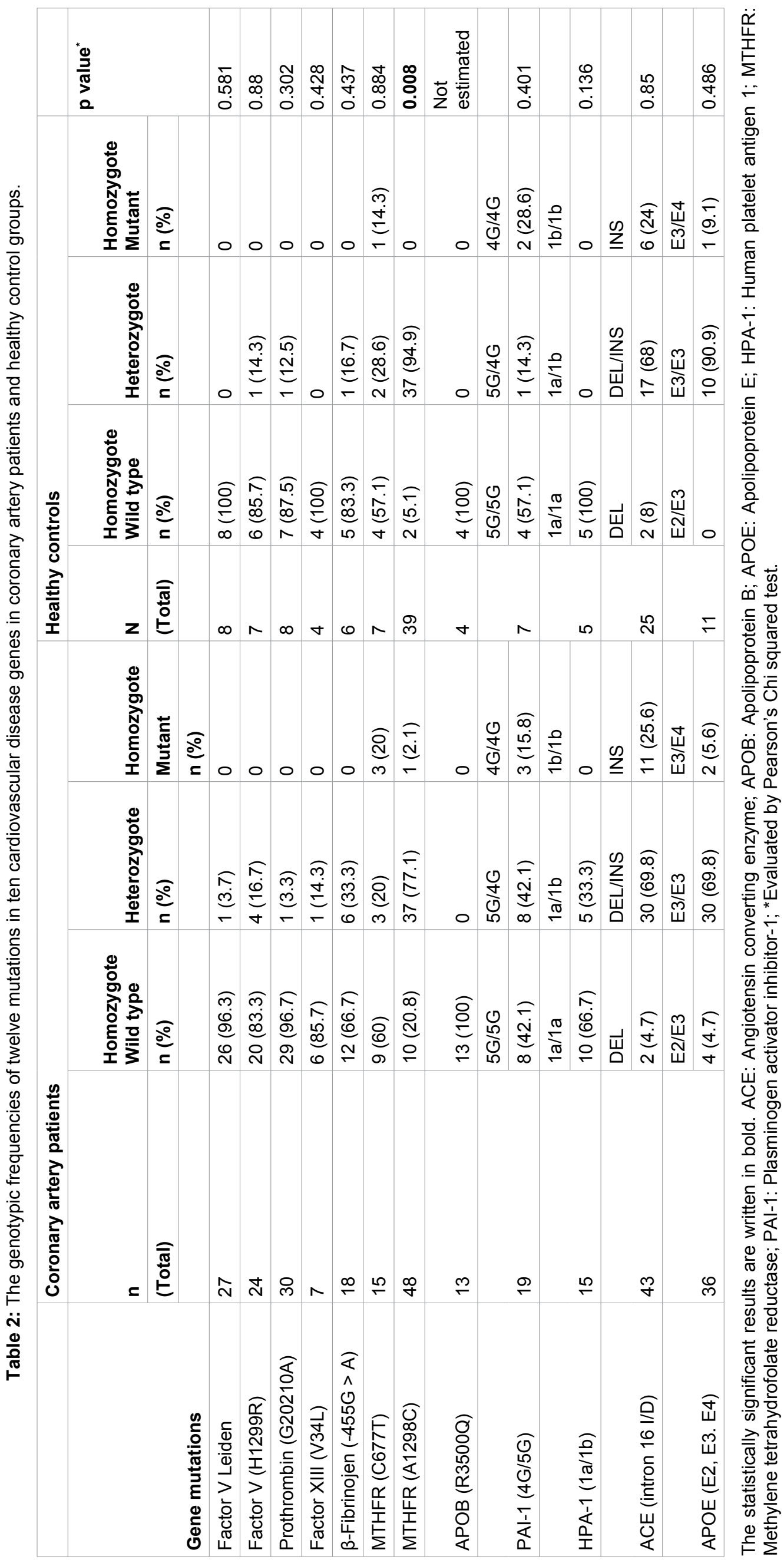


Table 3: Patients with Compound Genotype.

\begin{tabular}{|l|l|l|l|}
\hline Mutasyonlar & $\begin{array}{l}\text { Toplam Hasta } \\
\text { Sayısı }\end{array}$ & $\begin{array}{l}\text { Mutasyonu Birlikte } \\
\text { Taşıyan Hasta Sayısı }\end{array}$ & \begin{tabular}{l} 
Yüzde \\
\hline ACE I/D, MTHFR A1298C
\end{tabular} \\
\hline PAl-1 4G/5G, MTHFR A1298C, ACE I/D & 46 & 26 & 56 \\
\hline PAI-1 4G/5G, MTHFR A1298C, HPA-1 1a/1b, ACE I/D & 15 & 8 & 53 \\
\hline
\end{tabular}

ACE I/D) and in 5 (33\%) of 15 patients four mutations (PAI-1 4G/5G, MTHFR A1298C, HPA-1 1a/1b, ACE I/D) were found to be transported together (Table 3).

\section{Discussion}

CAD is a multifactorial disease and multifactorial diseases are caused by the interaction of genetic and environmental factors. Many genetic factors that cause coronary artery disease have been identified [7]. CAD plays an important role in clinical course of CVD $[4,8]$. For this reason, the CVD related gene mutations that were defined to CVD StripAssay are good candidates for genetic studies of CAD. In the current study, twelve gene mutations in the Factor $V$, Prothrombin, Factor XIII, $\beta$-Fibrinogen, PAI-1, HPA1, MTHFR, ACE, APOB and APOE genes were analyzed by CVD StripAssay on study population.

\section{FV Leiden (FVL) (1691G > A, R506Q, Arg506GIn)}

The frequency of FVL mutation in the normal population is generally $2-4 \%$. However, it was reported to be $3 \%$ in Europe, $4.4 \%$ in America, $14 \%$ in Greece, $7.1-10.3 \%$ in Turkey, and $12.2 \%$ in Northern Cyprus $[23,29,30]$. In our study, homozygote wild type and heterozygote frequencies were found to be $96.3 \%$ and $3.7 \%$ in the coronary artery patients group, respectively. In the control group, only homozygote wild type genotype was observed. Homozygote mutant genotype was not found in both groups. In another study from Turkish population including 4,709 individuals with cardiovascular disease, the frequency of FVL mutation was observed $0.57 \%$ in homozygous form and $7.43 \%$ in heterozygous form [31]. Close to the rates observed in this study, homozygous mutant genotype was not observed in our study. Although the number of samples in which this gene was studied was limited, the presence of mutant alleles in CAD patients, but not in healthy controls, revealed a possible relationship between CAD and FVL mutation.

\section{FV R2 haplotype (H1299R, His1299Arg) mutation}

In different regions of the world, the frequency of Arg allele was reported to be $9.5-16.5 \%$ in VTE cases; 5.8-10.4\% in healthy controls [32-37]. In our study, we didn't observed any Arg/Arg genotype in the analysis of His1299Arg mutation in both groups. In our study, the $\mathrm{His} / \mathrm{His}$ and $\mathrm{His} / \mathrm{Arg}$ genotype frequencies were $83.3 \%$ and $16.7 \%$ in the coronary artery patients group and $85.7 \%$ and $14.3 \%$ in the healthy control group, respectively. Although in our study the sample size was limited, the rate of Arg allele in the patient group (8.3\%) was smaller than the findings of worldwide, but the frequency of Arg allele in our control group (7.1\%) was found to be similar to the findings of worldwide. In another study with the similar number of samples we studied, in order to investigate the role of various homeostatic gene polymorphisms in young patients in Egypt, including $31 \mathrm{MI}, 21$ unstable angina and 20 controls, the frequency of $\mathrm{H} 1299 \mathrm{R}$ mutation was found to have no difference between patients and controls similar to our results [38].

\section{Prothrombin G20210A mutation}

In our study, only GG and GA genotypes were observed among the genotypes identified as GG, GA and $A A$ in the prothrombin gene. While 29 (96.7\%) of 30 patients with coronary artery disease had wild type GG, $1(3.3 \%)$ had heterozygous GA genotype, in the control group which was very low in size, 6 of 7 samples had GG and 1 had GA genotype. No AA genotype was found in either group. Any statistically significant difference was not observed between patients and controls in terms of Prothrombin G20210A mutation. In another study including $96 \mathrm{Ml}$ patients and 77 controls from the south region of Turkey, Dönmez, et al. has been reported that there was no relationship between $\mathrm{Ml}$ development and this variant (P: 0.4) [39]. According to results of another study from Turkey including 4,709 patients, the frequency of mutation in the homozygous form was found $0.25 \%$, and in heterozygous form it was found to be $3.44 \%$ similar to our results [31].

\section{Factor XIII Val34Leu (V34L) mutation}

The frequency of Factor XIII Val34Leu mutation is $25 \%$ in the white, lower in black people and Asian Indians, and extremely rare in the Japanese population [40]. In a separate case-control study in Hungary, FXIII-Leu34 amino acid exchange was found to provide protection against $\mathrm{MI}[40,41]$. A study in the Aegean Region in Turkey supports the FXIII Val/ Leu genotype has a protective effect from MI [42]. In our study, among the genotypes identified as Val/ Val, Val/Leu and Leu/Leu in the Factor XIII gene, 6 of 7 patients had homozygous Val genotype, 1 patient had heterozygous Val/Leu genotype and 4 individuals in the control group had homozygous Val genotype. Homozygous Leu genotype was not found in both groups. Unlike other mutations, there was no evidence for the protective effect of the Val/Leu genotype due to the limited number of samples studied 
for the Val34Leu mutation. In our study for factor XIII mutation, the loss data due to the Strip Assay were quite high.

\section{B-Fibrinojen -455G > A mutation}

In our study, only GG and GA genotypes were observed in the genotypes identified as GG, GA and $A A$ in the $\beta$-fibrinogen gene and their frequency was $66.7 \%$ and $33.3 \%$ in the coronary artery patient group, and $83.3 \%$ and $16.7 \%$ in the control group, respectively. No AA homozygous mutant genotype was observed in either group. No association was found between AA genotype and CAD in our study. In a study conducted in Kayseri in Turkey, which included 35 coronary artery patients, $-455 \mathrm{~A}$ alleles were found to have no effect on the development and severity of CAD [43]. In a similar study in Poland, 426 ischemic stroke patients and 234 controls were examined. Genotype frequencies were GG 75\%, GA $36.8 \%$, AA $6.6 \%$ in patient group and GG 5.3\%, GA $32.9 \%$ and AA $9.8 \%$ in control group, and no significant difference was found between the patient and control groups in terms of this mutation [44]. GA genotype frequency, which is $33.3 \%$ in our patient group, is similar to the genotype frequency in the study conducted in Poland.

\section{PAI-1 4G/5G mutation}

In our study, the frequency of genotypes identified as $5 \mathrm{G} / 5 \mathrm{G}, 4 \mathrm{G} / 4 \mathrm{G}$ and $5 \mathrm{G} / 4 \mathrm{G}$ were $42.1 \%, 15.8 \%, 42.1 \%$ in the coronary artery patient group and $57.1 \%, 2.6 \%$, $14.3 \%$ in the control group respectively. It was observed that $4 \mathrm{G}$ allele was higher in the coronary artery group. Similar to our findings, in a study including $127 \mathrm{MI}$ and 127 controls in Mexico, it was found that $4 \mathrm{G}$ allele was an independent risk factor for young acute $\mathrm{Ml}$ in smokers, hypertension patients and that having family history [45]. In another study involving $305 \mathrm{MI}$ patients and 328 controls, the risk of MI was found to be high with increased plasma PAI-1 levels in 4G carriers [46].

\section{HPA-1 (1a/1b) mutation}

In our study, only $1 a / 1 a$ and $1 a / 1 b$ genotypes of the genotypes identified as $1 a / 1 a, 1 a / 1 b$ and $1 b / 1 b$ in the HPA1 gene were observed. These genotype frequencies were $66.7 \%, 33.3 \%$ in coronary artery patient group, respectively. In the control group, only the $1 \mathrm{a} / 1$ a genotype was observed. Any $1 \mathrm{~b} / 1 \mathrm{~b}$ genotype was found in either group. Some studies have shown that HPA-1b homozygote individuals have high risk for ischemic cardiovascular disease and MI $[47,48]$. In contrast, a study from Sweden including 369 patients and 388 controls revealed that HPA-1 gene mutation was not associated with coronary atherosclerosis or MI [49]. In addition, studies including 510 CAD patients in the USA and 1211 CAD patients in Germany have reported that the HPA$1 \mathrm{~b}$ allele causes early MI but is not associated with CAD [50]. These differences may be due to factors such as the number of samples studied or ethnic origin.

\section{MTHFR C677T and A1298C mutations}

In our study, the frequency of genotypes identified as CC, CT and TT for MTHFR C677T mutation were estimated as $60 \%, 20 \%$ and $20 \%$ in coronary artery patients group, $57.1 \%, 28.6 \%$ and $14.3 \%$ in control group, respectively. Although the frequency of TT genotype was higher in the patient group compared to the control group, a complete association with CAD could not be made due to the limited number of samples. In another study from Turkey conducted by Yilmaz, et al. with 93 healthy controls and 79 coronary artery patients for 677C > T mutation, no statistically significant difference was found between patient and control groups in terms of this mutation $(p>0.05)$ [51]. In contrast to this study, another study conducted in China, involving 694 hyperlipidemia patients and 897 controls, found that those carrying the TT genotype had higher plasma homocysteine values $(p<0.01)[52]$.

In our study regarding the MTHFR A1298C mutation, the frequency of genotypes identified as $A A, A C$, CC were $20.8 \%, 77.1 \%, 2.1 \%$ in the coronary artery patient group, $5.1 \%, 94.9 \%, 0 \%$ in the control group, respectively. When AA: AC + CC genotypes were compared between patient and control groups, heterozygous and homozygous mutant genotypes had shown to have protective effects against CAD [p $=0.06, O R$ $=0.205(0.0421-1.001)$ in $95 \%$ confidence interval $]$. In another study conducted in Turkey including 86 coronary artery patients and 90 controls, no correlation was found between CAD and A1298C mutation [53]. However, in another study performed in Turkey with 79 conotruncal heart patients and 99 controls, AC and CC genotypes were observed to be significantly higher in patient group and $\mathrm{A} 1298 \mathrm{C}$ mutation was found to be a risk factor for conotruncal heart disease $(p<0.05)[54]$.

\section{ACE I/D mutation}

In our study, the frequency of genotypes identified as II, DI and DD in the ACE gene were determined as $4.7 \%, 69.8 \%, 25.6 \%$ in coronary artery patients group, and $8 \%, 68 \%, 24 \%$ in the control group, respectively. DI and DD genotype frequencies were similar in both groups. When the genotype frequencies of both groups were compared, no correlation was found between this mutation and CAD $[p=0.89, O R=1.089$ (0.346-3.42)]. In a study conducted in Iran including 676 patients with coronary artery disease and 374 controls, ACE I/D mutation had found to have no effect on the development of CAD, similar to our findings [55]. However, in a study conducted in Turkey with 203 coronary artery patients and 140 controls, DD genotype was found to be higher in the patient group [56]. 


\section{APOB R3500Q mutation}

In our study, heterozygote and homozygote mutant genotypes of APOB R3500Q mutation was not observed in both groups. In a similar study involving 163 CAD patients and 114 controls held in Turkey, APOB R3500Q mutation was not observed in both groups, either [57]. In another study from Lebanon, this mutation has not been observed and it has been reported that this mutation may increasingly be lost in Mediterranean countries such as Israel, Spain and Turkey [58].

\section{APOE mutations}

In our study, the frequency of E2/E3 genotype was $11.1 \%$ in the coronary artery patients group and $0 \%$ in the control group; the frequency of E3/E3 genotype was $83.3 \%$ in the coronary artery patients group and $90.9 \%$ in the control group; the frequency of E3/ E4 genotype was $5.6 \%$ in the coronary artery patients group and $9.1 \%$ in the control group. Other genotypes were not found in either groups. The relationship with CAD and APOE mutation was not significant because there was no numerical match between patient-control groups due to data loss. In contrast to our study, E4 allele was found to be higher in another study from Turkey including 70 children with coronary artery disease and 67 controls and also in children with E4 allele, T-Arm and LDL levels were found to be high [59]. In a meta-analysis including 6634 CAD patients and 6394 controls from China, it was reported that the APOE E4 allele may be a risk factor for CAD [60].

\section{Patients with compound genotype}

When the mutations observed in the patient group were evaluated, it was observed that there were individuals carrying more than one mutation. These include; 26 of the 46 patients (56\%) had two mutations (ACE I/D, MTHFR A1298C); 8 of 15 patients (53\%) have three mutations (PAI-1 4G/5G, MTHFR A1298C, ACE I/D), 5 of 15 patients (33\%) have four mutations (PAI-1 4G/5G, MTHFR A1298C, HPA-1 1a/1b, ACE I/D). These findings suggest that the mutation of more than one gene in a person is a trigger for CAD due to the cumulative effect. It was found that high cholesterol, obstructed vessel count and smoking were higher in patients with CAD who had compound genotype or mutations in more than one gene.

One of the most important limitations of the current study is the small sample size and this lowers the statistical power. Because of the methodology and financial restrictions, we studied limited number of cases.

In conclusion, among the twelve mutations studied only the A1298C mutation in MTHFR gene showed an association with CAD. It was observed that the frequencies of heterozygous and homozygous mutant genotypes of A1298C mutation in MTHFR gene were significantly higher in control group than CAD patients.
Based on this result, we can say that $\mathrm{A} 1298 \mathrm{C}$ mutation in MTHFR gene had a protective effect against CAD. Furthermore, it was indicated that the cumulative effect of mutant genotypes and environmental factors may be a trigger for CAD in individuals with compound genotypes. To our knowledge it is the first study that investigated 12 mutations in ten cardiovascular related genes in CAD patients. In the mutation analysis of the 10 genes studied, we think that if the number of patients and controls is expanded, more predictive results can be obtained for CAD.

\section{Acknowledgments}

This study was supported by the Ondokuz Mayıs University Research Fund (Project No: PYO.TIP.1904.12.001) and is a report of Master of Science thesis.

\section{Declaration of Conflicting Interests}

The authors declare that they have no conflict of interest.

\section{References}

1. Li X, McGue M, Gottesman II (2012) Two sources of genetic liability to depression: interpreting the relationship between stress sensitivity and depression under a multifactorial polygenic model. Behav Genet 42: 268-277.

2. Bonow RO, Smaha LA, Smith SC Jr, Mensah GA, Lenfant C (2002) World Heart Day 2002: the international burden of cardiovascular disease: responding to the emerging global epidemic. Circulation 106: 1602-1605.

3. Levenson JW, Skerrett PJ, Gaziano JM (2002) Reducing the global burden of cardiovascular disease: the role of risk factors. Prev Cardiol 5: 188-199.

4. Hollander W (1976) Role of hypertension in atherosclerosis and cardiovascular disease. Am J Cardiol 38: 786-800.

5. Cervellin G, Lippi G (2014) Of Mls and men--a historical perspective on the diagnostics of acute myocardial infarction. Semin Thromb Hemost 40: 535-543.

6. Eichner JE, Dunn ST, Perveen G, Thompson DM, Stewart $\mathrm{KE}$, et al. (2002) Apolipoprotein e polymorphism and cardiovascular disease. A HuGE Review. Am J Epidemiol 155: 487-495.

7. Salazar LA, Hirata MH, Giannini SD, Forti N, Diament J, et al. (2000) Seven DNA Polymorphisms at the candidate genes of atherosclerosis in Brazilian women with angiographically document coronary artery diesease. Clin Chim Acta 300: 139-149.

8. Scannapieco FA, Bush RB, Paju S (2003) Associations between periodontal disease and risk for atherosclerosis, cardiovascular disease, and stroke. A systematic review. Ann Periodontol 8: 38-53.

9. Cambien F, Poirier O, Lecerf L, Evans A, Cambou JP, et al. (1992) Deletion polymorphism in the gene for angiotensin-converting enzyme is a potent risk factor for myocardial infarction. Nature 359: 641-644.

10. Agerholm-Larsen B, Nordestgaard BG, Tybjaerg-Hansen A (2000) ACE gene polymorphism in cardiovascular disease: meta-analyses of small and large studies in whites. Arterioscler Thromb Vasc Biol 20: 484-492.

11. Pullinger CR, Hennessy LK, Chatterton JE, Liu W, Love JA, 
et al. (1995) Familial liganddefective apolipoprotein B: identification of a new mutation that decreases LDL receptor binding affinity. J Clin Invest 95: 1225-1234.

12. Genest J Jr, McNamara JR, Ordovas JM, Jenner JL, Silberman SR, et al. (1992) Lipoprotein cholesterol, apolipoprotein A-I and B and lipoprotein (a) abnormalities in men with premature coronary artery disease. J Am Coll Cardiol 19: $792-802$.

13. Lane, DA, Grant PJ (2000) Role of hemostatic gene polymorphisms in venous and arterial thrombotic disease. Blood 95: 1517-1532.

14. Scarabin P, Bara L, Ricard S, Poirier O, Cambou JP, et al. (1993) Genetic variation at the beta-fibrinogen locus in relation to plasma fibrinogen concentrations and risk of myocardial infarction: the ECTIM study. Arterioscler Thromb 13: 886-891.

15. Behague I, Poirier O, Nicaud V, Evans A, Arveiler D, et al (1996) Beta-Fibrinogen gene polymorphisms are associated with plasma fibrinogen and coronary artery disease in patients with myocardial infarction: the ECTIM study. Circulation 93: 440-449.

16. Voetsch B, Loscalzo J (2004) Genetic Determinants of Arterial Thrombosis. Arterioscler Thromb Vasc Biol 24: 216229.

17. Mikkola H, Muszbek L, Haramura G, Hamalainen E, Jalanko A, et al. (1997) Molecular mechanisms of mutations in factor XIII A-subunit deficiency: in vitro expression in COScells demonstrates intracellular degradation of the mutant proteins. Thromb Haemostasis 77: 1068-1072.

18. Mikkola H, Muszbek L, Laiho E, Syrjala M, Hamalainen E, et al. (1997) Molecular mechanism of a mild phenotype in coagulation factor XIII (FXIII) deficiency: a splicing mutation permitting correct splicing of FXIII A-subunit mRNA. Blood 89: $1279-1287$.

19. Ariens RA, Philippou H, Nagaswami C, Weisel JW, Lane DA, et al. (2000) The factor XIII V34L polymorphism accelerates thrombin activation of factor XIII and affects crosslinked fibrin structure. Blood 96: 988-995.

20. Major DA, Sane DC, Herrington DM (2000) Cardiovascular implications of the factor $\mathrm{V}$ Leiden mutation. Am Heart $\mathrm{J}$ 140: 189-195.

21. Reiner AP, Rosendaal FR, Reitsma PH, Lemaitre RN, Pearce RM, et al. (2002) Factor $V$ leiden, prothrombin G20210A and risk of sudden coronary death in apparently healty persons. Am J Cardiol 90: 66-68.

22. Zöller B, Svensson PJ, He X, Dahlback B (1994) Idendification of the same factor $V$ Leiden mutation in 47 out of 50 thrombosisprone families with inherited resistance to activated protein C. J Clin Invest 94: 2521-2524.

23. Slowik A, Dziedzic T, Turaj W, Pera J, Glodzik-Sobanska L, et al. (2004) A2 alelle of Gpllla gene is a risk factor for stroke caused by large-vessel disease in males. Stroke 35: 1589-1593.

24. Kang SS, Wong PW, Susmano A, Sora J, Norusis M, et al (1991) Thermolabile methylenetetrahydrofolate reductase: An Inherited risk factor for coronary artery disease. J Hum Genet 48: 536-545.

25. Nauck M, Wieland H, März W (1999) Rapid, homogeneous genotyping of the $4 \mathrm{G} / 5 \mathrm{G}$ polymorphism in the promoter region of the PAll gene by fluorescence resonance energy transfer and probe melting curves. Clin Chem 45: 11411147.
26. Poort SR, Rosendaal FR, Reitsma PH, Bertina RM (1996) A common genetic variation in the 3-prime-untranslated region of the prothrombin gene is associated with elevated plasma prothrombin levels and an increase in venous thrombosis. Blood 88: 3698-3703.

27. Poirier J, Davignon J, Bouthillier D, Kogan S, Bertrand P, et al. (1993) Apolipoprotein E polymorphism and Alzheimer's disease. Lancet 34: 697-699.

28. Akar N, Akar E, Dalgin G, Sözüöz A, Omürlü K, et al. (1997) Frequency of Factor $\mathrm{V}(1691 \mathrm{G}-->\mathrm{A})$ mutation in Turkish population. Thromb Haemost 78: 1527-1528.

29. Gurgey A, Mesci L, Renda Y, Olcay L, Kocak N, et al. (1996) Factor V Q 506 mutation in children with thrombosis. Am J Hematol 53: 37-39.

30. Gül A, Ozbek U, Oztürk C, Inanç M, Koniçe M, et al. (1996) Coagulation factor $\mathrm{V}$ gene mutation increases the risk of venous thrombosis in Behçet's disease. $\mathrm{Br} \mathrm{J}$ Rheumatol 35: 1178-1180.

31. Öztuzcu S, Ergun S, Ulaşlı M, Nacarkahya G, Iğci $Y Z$, et al. (2014) Evaluation of Factor $V$ G1691A, prothrombin G20210A, Factor XIII V34L, MTHFR A1298C, MTHFR C677T and PAl-1 4G/5G genotype frequencies of patients subjected to cardiovascular disease (CVD) panel in southeast region of Turkey. Mol Biol Rep 41: 3671-3676.

32. Bernardi F, Faioni EM, Castoldi E, Lunghi B, Castaman G, et al. (1997) A factor $V$ genetic component differing from factor $V$ R506Q contributes to the activated protein $C$ resistance phenotype. Blood 90: 1552-1557.

33. Castoldi E, Rosing J, Girelli D, Hoekema L, Lunghi B, et al. (2000) Mutations in the R2 FV gene affect the ratio between the two FV isoforms in plasma. Thromb Haemost 83: 362365.

34. Pecheniuk NM, Morris CP, Walsh TP, Marsh NA (2001) The factor $V$ HR2 haplotype: prevalence and association of the A4070G and A6755G polymorphisms. Blood Coagul Fibrinolysis 12: 201-206.

35. Margaglione M, Bossone A, Coalizzo D, D'Andrea G, Brancaccio V, et al. (2002) FV HR2 haplotype as additional inherited risk factor for deep vein thrombosis in individuals with a high- risk profile. Thromb Haemost 87: 32-36.

36. Faioni EM, Castaman G, Asti D, Lussana F, Rodeghiero F (2004) Association of factor $V$ deficiency with factor V HR2. Haematologica 89: 195-200.

37. Jadaon MM, Dashti AA (2005) HR2 haplotype in Arab population and patients with venous thrombosis in Kuwait. J Thromb Haemost 3: 1467-1471.

38. Alkhiary W, Azzam H, Yossof MM, Aref S, Othman M, et al. (2016) Association of hemostatic gene polymorphisms with early-onset ischemic heart disease in egyptian patients. Clin Appl Thromb Hemost 22: 535-542.

39. Dönmez Y, Kanadasi M, Tanriverdi K, Demir M, Demirtaş M, Çaylı M, et al. (2004) Prothrombin 20210GA and factor $\checkmark$ Leiden mutations in 81 patients less than 55 years old with myocardial infarction. Jpn Heart J 45: 505-512.

40. Muszbek L (2000) Deficiency causing mutations and common polymorphisms in the factor XIII-A gene. Thromb Haemost 84: 524-527.

41. Mezei ZA, Bereczky Z, Katona É, Gindele R, Balogh E, et al. (2015) Factor XIII B subunit polymorphisms and the risk of coronary artery disease. Int J Mol Sci 16: 1143-1159.

42. Tug E, Aydın H, Kaplan E, Doğruer D (2011) Frequency of genetic mutations associated with thromboembolism in the Western Black Sea Region. Intern Med 50: 17-21. 
43. Gül İbrahim (2006) Beta fibrinogen 455G/A, Factor $V$ 1691G/A and 1299H/A, Glycoprotein IIB/IIIA PL A1/A2 polymorphisms in patients with acute coronary syndrome. Erciyes University Medical Faculty Cardiology Department, Kayseri, Turkey, PhD thesis.

44. Golenia A, Chrzanowska-Wasko J, Jagiella J, Wnuk M, Ferens A, Klimkowicz-Mrowiec A, et al. (2013) The $\beta$-fibrinogen $-455 \mathrm{G} / \mathrm{A}$ gene polymorphism and the risk of ischaemic stroke in a Polish population. Neurol Neurochir Pol 47: 152-156.

45. Isordia-Salas I, Leaños-Miranda A, Sainz IM, Reyes-Maldonado E, Borrayo- Sa'nchez G (2009) Association of the plasminogen activator inhibitor-1 gene $4 \mathrm{G} / 5 \mathrm{G}$ polymorphism with ST elevation acute myocardial infarction in young patients. Rev Esp Cardiol 62: 365-372.

46. Abboud N, Ghazouani L, Saidi S, Ben-Hadj-Khalifa S, Addad F, Almawi WY, et al. (2010) Association of PAl-1 4G/5G and $-844 \mathrm{G} / \mathrm{A}$ gene polymorphisms and changes in PAI-1/ tissue plasminogen activator levels in myocardial infarction: a casecontrol study. Genet Test Mol Biomarkers 14: 23-27.

47. Moshfegh K, Wuillemin WA, Redondo M, Lämmle B, Beer $\mathrm{JH}$, et al. (1999) Association of two silent polymorphisms of platelet glycoprotein la/lla receptor with risk of myocardial infarction: a case-control study. Lancet 353: 351-354.

48. Böttiger C, Kastrati A, Koch W, Mehilli J, Seidl H, et al. (2000) HPA-1 and HPA-3 polymorphisms of the platelet fibrinogen receptor and coronary artery disease and myocardial infarction. Thromb Haemost 83: 559-562.

49. Lagercrantz J, Bergman M, Lundman P, Tornvall P, Hjemdahl P, et al. (2003) No evidence that the PLA1/PLA2 polymorphism of platelet glycoprotein IIla is implicated in angiographically characterized coronary atherosclerosis and premature myocardial infarction. Blood Coagul Fibrinolysis 14: 749-753.

50. Zotz RB, Winkelmann BR, Müller C, Boehm BO, März W, et al. (2005) Association of polymorphisms of platelet membrane integrins alpha IIb (beta) 3 (HPA-1b/PI) and alpha2 (beta) 1 (alpha807TT) with premature myocardial infarction. J Thromb Haemost 3: 1522-1529.

51. Yilmaz H, Isbir S, Agachan B, Ergen A, Farsak B, et al. (2006) C677T mutation of methylenetetrahydrofolate re- ductase gene and serum homocysteine levels in Turkish patients with coronary artery disease. Cell Biochem Funct 24: 87-90.

52. Liang R, Zhou Y, Xie J, Lv W, Kang B, et al. (2014) Association of C677T gene polymorphisms of methylenetetrahydrofolate reductase and plasma homocysteine level with hyperlipidemia. Nan Fang Yi Ke Da Xue Xuen Bao 34: 1195-1198.

53. Var A, Utük O, Akçali S, Sanlidağ T, Uyanik BS, et al. (2009) Impact of hemostatic gene single point mutations in patients with non-diabetic coronary artery disease. Mol Biol Rep 36: 2235-2243.

54. Sayin Kocakap BD, Sanli C, Cabuk F, Koc M, Kutsal A (2015) Association of MTHFR A1298C polymorphism with conotruncal heart disease. Cardiol Young 25: 1326-1331.

55. Poorgholi L, Saffar H, Fathollahi MS, Davoodi G, Anvari MS, et al. (2013) Angiotensin converting enzyme insertion/ deletion polymorphism and its association with coronary artery disease in an Iranian population. J Tehran Heart Cent 8: 89-94.

56. Guney Al, Ergec D, Kirac D, Ozturhan H, Caner M, et al. (2013) Effects of ACE polymorphisms and other risk factors on the severity of coronary artery disease. Genet Mol Res 12: 6895-6906.

57. Eroğlu Z, Selvi N, Kosova B, Biray C, Kumral E, et al. (2008) Absence of apolipoprotein B-3500 mutation in Turkish patients with coronary and cerebrovascular atherosclerosis. Anadolu Kardiyol Derg 8: 7-9.

58. Sabbagh AS, Daher RT, Otrock ZK, Khalek RN, Zaatari GS, et al. (2007) ApoB-100 R3500Q mutation in the Lebanese population: prevalence and historical review of the literature. Mol Biol Rep 34: 267-270.

59. Ciftdoğan DY, Coskun S, Ulman C, Tıkız H (2012) The association of apolipoprotein $\mathrm{E}$ polymorphism and lipid levels in children with a family history of prematurecoronary artery disease. J Clin Lipidol 6: 81-87.

60. Zhang MD, Gu W, Qiao SB, Zhu EJ, Zhao QM, et al. (2014) Apolipoprotein $\mathrm{E}$ gene polymorphism and risk for coronary heart disease in the Chinese population: a meta-analysis of 61 studies including 6634 cases and 6393 controls. PLoS One 9: 1-9. 